\title{
Enquete do Jornal Vascular Brasileiro
}

\author{
Survey of Jornal Vascular Brasileiro
}

\author{
Winston Bonetti Yoshida*
}

Há alguns meses tomei a iniciativa de criar uma enquete (veja endereço nesta edição) e solicitei aos sócios da Sociedade Brasileira de Angiologia e Cirurgia Vascular (SBACV) que respondessem a algumas perguntas e nos enviassem sugestões para melhorarmos o Jornal Vascular Brasileiro. Houve adesão significativa, com cerca de 500 respostas até o início de dezembro de 2010. Trata-se de amostra significativa dentre o universo de cerca de 3.000 sócios, mas gostaria de ainda maior representatividade. Por esse motivo, estou escrevendo este editorial, procurando sensibilizar nossos colegas a contribuírem com suas opiniões e sugestões, visando tornar o Jornal Vascular Brasileiro uma revista de prestígio nacional e até mesmo internacional.

O Jornal Vascular Brasileiro, por ter sistema de peer review (revisão por pares), padronização, periodicidade e tradição (como sucessor da revista Cirurgia Vascular e Angiologia que foi impressa de 1984 a 2001), teve indexação precoce nas bases de dados Lilacs e SciELO, o que ajudou muito a alavancar sua importância e impacto. No sentido de resgatar a história da produção científica da SBACV antes do Jornal Vascular Brasileiro, iniciamos, com o apoio da Diretoria da SBACV, do Dr. Ayrton D. Frankini (que disponibilizou sua coleção completa) e dos editores detentores do título, o processo de digitalização de todos os artigos da revista "Cirurgia Vascular e Angiologia", para figurar em nossa página da internet como artigo completo (www.jvascbr.com.br).

Desconheço revistas similares exclusivas sobre Cirurgia Vascular e Angiologia na América Latina, o que representa pioneirismo para o Jornal Vascular Brasileiro e de sua antecessora, como veículos de informação na área nesse continente. Por outro lado, apesar de convites formais para todas as Sociedades de Cirurgia Vascular Latino-Americanas, ainda temos recebido poucas contribuições de países vizinhos. No Brasil, temos produção significativa de cerca de 600

temas livres por congresso, dos quais somente 6,3\% são publicados em revistas indexadas ${ }^{1,2}$. É preciso aumentar essa frequência, e espero encontrar sugestões na enquete para incrementar submissões tanto desses países vizinhos como dos nossos sócios.

Para trabalharmos na editoração com maior tranquilidade e pontualidade, precisamos de pelo menos 150 submissões por ano. Estivemos muito perto de atingir essa meta, até que a Coordenação de Aperfeiçoamento de Pessoal de Nível Superior CAPES resolveu modificar, em 2009, o critério de qualificação das revistas nacionais com base no fator de impacto, em competição direta com revistas internacionais de larga tradição, algumas delas com mais de 200 anos de atividade. Como nossa revista é emergente e tem poucos anos de existência, vamos precisar dos indexadores internacionais para recuperar a submissão de artigos em número e qualidade. Nunca é demais lembrar que o impacto da revista é calculado com base nas citações obtidas dos autores. Portanto, é muito importante que artigos nacionais, principalmente do J Vasc Bras, sejam procurados no Lilacs e SciELO e, se preencherem os critérios de qualidade e pertinência, sejam citados.

A qualidade dos artigos deve ser assegurada pelo processo de revisão por pares. Os revisores devem ter qualificação e presteza para garantir a qualidade das nossas publicações. Estamos em processo de avaliação pelo ISI da Thomson Reuters que, entre vários critérios, analisa número e impacto das publicações dos revisores do corpo editorial. Da mesma forma procede o PubMed/ Medline. Portanto, precisamos de revisores produtivos e com alto grau de qualificação para alcançarmos os indexadores internacionais mais importantes. Sendo assim, os colegas que têm título de Doutor em curso credenciado pela CAPES e publicações em número e impacto estão convidados a nos enviar um resumo curricular para figurarem em nosso corpo editorial e ajudar no crescimento do jornal. 
Finalmente, gostaria de agradecer aos autores e revisores, que trabalharam para compor as edições de 2010, aos colegas que responderam à nossa enquete e aos leitores do Jornal Vascular Brasileiro, desejando Feliz Ano Novo e muitas novas submissões para 2011. Aproveitem o tempo livre para compor os temas livre do nosso próximo congresso em São Paulo e os enviem para o J Vasc Bras.

\section{Referências}

1. Yoshida WB. Temas livres versus publicação. J Vasc Bras. 2005;4(4):319-20.

2. Yoshida WB, Holmo NF, Corregliano GT, Baldon KM, Souza, Silva N. Publicações indexadas geradas a partir de resumos de congressos de angiologia e cirurgia vascular no Brasil. J Vasc Bras. 2008;7(4):293-7. 